\title{
Seed Yield and Nutrient Uptake of Sunflower (Helianthus annuus L.) as Influenced by Different Levels of Boron and Potassium in Sandy Loam Soil
}

\author{
P. Jyothi ${ }^{1}$, T. Anjaiah ${ }^{1}$, I.Y.L.N. Murthy ${ }^{2}{ }^{*}$, Rajeshwar Naik $^{1}$ and S.A. Hussain ${ }^{1}$ \\ ${ }^{1}$ Department of Soil Science and Agricultural Chemistry, College of Agriculture, PJTSAU, \\ Rajendranagar, Hyderabad- 500 030, Telangana, India \\ ${ }^{2}$ ICAR-Indian Institute of Oilseeds Research, Rajendranagar, Hyderabad- 500030 , \\ Telangana, India
}

*Corresponding author

\section{A B S T R A C T}

\begin{tabular}{|l|}
\hline Ke y w o r d s \\
Alfisol, boron, \\
$\begin{array}{l}\text { Nitrogen, } \\
\text { Phosphorus, } \\
\text { Potassium, Nutrient } \\
\text { uptake, sunflower }\end{array}$ \\
\hline Article Info \\
\hline $\begin{array}{l}\text { Accepted: } \\
\text { 26 June } 2018 \\
\text { Available Online: } \\
\text { 10 July } 2018\end{array}$ \\
\hline
\end{tabular}

A field experiment was laid out in factorial randomized block design with 16 treatment combination comprising of four levels of boron and four levels of potassium viz., $\left(\mathrm{B}_{0} \mathrm{~K}_{0}\right)$, $\left(\mathrm{B}_{0} \mathrm{~K}_{15}\right),\left(\mathrm{B}_{0} \mathrm{~K}_{30}\right),\left(\mathrm{B}_{0} \mathrm{~K}_{60}\right),\left(\mathrm{B}_{0.5} \mathrm{~K}_{0}\right),\left(\mathrm{B}_{0.5} \mathrm{~K}_{15}\right),\left(\mathrm{B}_{0.5} \mathrm{~K}_{30}\right),\left(\mathrm{B}_{0.5} \mathrm{~K}_{60}\right),\left(\mathrm{B}_{1} \mathrm{~K}_{0}\right),\left(\mathrm{B}_{1} \mathrm{~K}_{15}\right),\left(\mathrm{B}_{1} \mathrm{~K}_{30}\right)$, $\left(\mathrm{B}_{1} \mathrm{~K}_{60}\right),\left(\mathrm{B}_{1.5} \mathrm{~K}_{0}\right),\left(\mathrm{B}_{1.5} \mathrm{~K}_{15}\right),\left(\mathrm{B}_{1.5} \mathrm{~K}_{30}\right),\left(\mathrm{B}_{1.5} \mathrm{~K}_{60}\right)$ to investigate the influence of application of different levels of boron and potassium with recommended dose of $\mathrm{N}$ and $\mathrm{P}$ fertilizers on sunflower (Helianthus annuus L.) hybrid,GK-2002 to find out the nutrient (Nitrogen, phosphorus, potassium and boron) uptake and optimum dosage of boron and potassium to increase the sunflower seed yield. In the present investigation, sunflower shoot uptake of major nutrients like $\mathrm{N}$ and $\mathrm{P}$ were significantly influenced by the application of $\mathrm{B}$ and $\mathrm{K}$ at 60 and 90 DAS. Nutrient uptake by sunflower seed increased with increasing levels of boron and potassium application. Seed nutrient uptake of N, P, K and B were 43.83, 11.85, $13.65 \mathrm{~kg} \mathrm{ha}^{-1}$ and $33.24 \mathrm{~kg} \mathrm{ha}^{-1}$, respectively with $\mathrm{B}_{1.5} \mathrm{~K}_{60}$, which is at par with $\mathrm{B}_{1} \mathrm{~K}_{30}$ treatment. Maximum seed yield was obtained with $\mathrm{B}_{1.5} \mathrm{~K}_{60}$ treatment fallowed by $\mathrm{B}_{1.5} \mathrm{~K}_{30}$, $\mathrm{B}_{1} \mathrm{~K}_{30}$ and $\mathrm{B}_{1} \mathrm{~K}_{60}$. Boron and potassium levels and $\mathrm{B} \times \mathrm{K}$ interaction were found significant in both shoot and seed. Even though highest seed yield with $\mathrm{B}_{1.5} \mathrm{~K}_{60}$ treatment was recorded, $\mathrm{B}_{1} \mathrm{~K}_{30}$ treatment showed was economically beneficial.

\section{Introduction}

Sunflower (Helianthus annuus $\mathrm{L}$ ) is one of the important edible oilseed crops cultivated in India in various soil types. Soil fertility in terms of nutrient sufficiency and deficiency for all types of Indian soils is well documented (Sahrawatet al 2007, Pathak 2010, Shukla et al 2014). Sunflower growing soils of Telangana State are found to be deficient in important nutrients viz. nitrogen, potassium, sulphur, zinc and boron (Regoet al., 2007, Murthy et al., 2009, Bhupal Raj et al., 2009) which are highly essential to attain higher seed yield and oil quality. Sunflower is one of the most sensitive crops to B deficiency. Boron deficiency symptoms in sunflower become evident on leaves, stems, reproductive parts, dry matter, yield components and seed yield. Asadet al., (2003) reported that B requirement 
of sunflower during reproductive growth is higher than during vegetative growth. At flowering, B deficiency can affect pollen viability and abortion of stamens and pistils which contribute to poor seed set due to malformed capitulums and consequently low seed yield (Chatterjee and Nautiyal, 2000). Potassium plays key role in increasing crop yield and improving the quality of product (Soleimanzadeh et al., 2010). Application of potassium plays a remarkable role in boosting up production (Blamey et al., 1979). The effect of potassium application on sunflower plant growth, yield and quality was reported by some investigators, who found that increasing potassium level led to a significant increase in plant height (Sirbu and Ailincai, 1992), number of leaves, leaf area and head diameter (Lewis et al., 1991).

Boron and potassium have overlapping roles to play in plant physiology and hence, are synergistic. Like potassium, boron is also involved in some aspects of flowering and fruiting processes, pollen germination, cell division, nitrogen metabolism, carbohydrate metabolism, active salt absorption, hormone movement and action, water metabolism and the water relations in plants. They both serve in acting as a buffer and are necessary in the maintenance of conducting tissues and to exert a regulatory effect on other elements. It has been shown that an optimal level of boron increases potassium permeability in the cell membrane (Ujwala, 2011). Keeping this in view a field study was conducted in sandy loam soil to assess the seed yield and nutrient uptake of sunflower as influenced by different levels of boron and potassium.

\section{Materials and Methods}

Afield experiment was conducted on sandy loam soil at Agricultural College farm, Rajendranagar, Hyderabad during Rabi, 2016. The experimental field was moderately alkaline in soil reaction ( $\mathrm{pH} 8.24)$, non-saline, and low in organic carbon $(0.42 \%)$ content. The chemical properties of soil showed that it was medium in nitrogen (294 $\mathrm{kg} \mathrm{ha}^{-1}$ ), phosphorus $\left(30 \mathrm{~kg} \mathrm{ha}^{-1}\right.$ ) and potassium (204.2 $\mathrm{kg} \mathrm{ha}^{-1}$ ) and deficient in available soil boron i.e. $0.4 \mathrm{mg} \mathrm{kg}^{-1}$.

The experiment was laid out in factorial randomized block design with 16 treatment combination comprising of four levels of boron and four levels of potassium viz., $\mathrm{T}_{1}\left(\mathrm{~B}_{0}\right.$ $\left.\mathrm{K}_{0}\right), \mathrm{T}_{2}\left(\mathrm{~B}_{0} \mathrm{~K}_{15}\right), \mathrm{T}_{3}\left(\mathrm{~B}_{0} \mathrm{~K}_{30}\right), \mathrm{T}_{4}\left(\mathrm{~B}_{0} \mathrm{~K}_{60}\right), \mathrm{T}_{5}$ $\left(\begin{array}{llllll}\mathrm{B}_{0.5} & \mathrm{~K}_{0}\end{array}\right), \quad \mathrm{T}_{6} \quad\left(\mathrm{~B}_{0.5} \mathrm{~K}_{15}\right), \quad \mathrm{T}_{7}\left(\mathrm{~B}_{0.5} \mathrm{~K}_{30}\right), \mathrm{T}_{8}$ $\left(\mathrm{B}_{0.5} \mathrm{~K}_{60}\right), \mathrm{T}_{9}\left(\mathrm{~B}_{1} \mathrm{~K}_{0}\right), \mathrm{T}_{10}\left(\mathrm{~B}_{1} \mathrm{~K}_{15}\right), \mathrm{T}_{11}\left(\mathrm{~B}_{1} \mathrm{~K}_{30}\right)$, $\mathrm{T}_{12}\left(\mathrm{~B}_{1} \mathrm{~K}_{60}\right), \mathrm{T}_{13}\left(\mathrm{~B}_{1.5} \mathrm{~K}_{0}\right), \mathrm{T}_{14}\left(\mathrm{~B}_{1.5} \mathrm{~K}_{15}\right), \mathrm{T}_{15}$ $\left(\mathrm{B}_{1.5} \mathrm{~K}_{30}\right), \mathrm{T}_{16}\left(\mathrm{~B}_{1.5} \mathrm{~K}_{60}\right)$ with recommended dose of $\mathrm{N}$ and $\mathrm{P}$ fertilizers on sunflower hybrid GK-2002. All the need based crop management practices were followed as in vogue. Dry matter accumulation was recorded at 60 DAS and 90 DAS by randomly tagging five plants from each plot which were cut from the base at each stage and separated into leaf + stem and head. They were shade dried and later oven dried at $65^{\circ} \mathrm{C}$ till constant weight was obtained. The oven dried weight of leaf, stem and head were recorded and pooled. Plant samples were digested with diacid mixture of 9:4 $\left(\mathrm{HNO}_{3}: \mathrm{HClO}_{4}\right)$ (Piper, 1966). Nitrogen content in plant samples were estimated by modified microkjeldahl method (Piper, 1966). Phosphorus content was determined by Vanado-molybdophosphoric yellow colour method using Spectrophotometer at $420 \mathrm{~nm}$. And potassium content was determined with ELICO - Flame Photometer (Piper, 1966).Boron content was determined by dry ashing in muffle furnace at $550^{\circ} \mathrm{C}$ for $2-3$ hours and subsequent extraction with $0.1 \mathrm{~N} \mathrm{HCl}$ (Gaines and Mitchell, 1979). Nutrient uptake was computed by multiplying the respective nutrient content with corresponding drymatter/seed yield and expressed in $\mathrm{kg} \mathrm{ha}^{-1}$. At harvest sunflower seed yield was recorded. 


\section{Results and Discussion}

Effect of boron and potassium levels on drymatter[sunflower shoot (leaf + stem and head)]yield, uptake of nitrogen, phosphorus, potassium and boron at 60 and 90 days after sowing is presented in table 1 and discussed below.

\section{Dry matter}

At 60 DAS, boron levels had significant effect on drymatter. Among all the treatments highest dry matter production was recorded in $\mathrm{B}_{1.5} \mathrm{~kg} \mathrm{ha}^{-1}+\mathrm{K}_{60} \mathrm{~kg} \mathrm{ha}^{-1}$. Significantly lowest dry matter production was recorded in control. Whereas drymatter production was significantly highest at $\mathrm{B}_{1.5} \mathrm{~K}_{60}$ as compared to control. The results revealed that dry matter production increased with increasing levels of boron and potassium. The $\mathrm{B} \times \mathrm{K}$ interaction effects were also found significant on drymatter production. The synergistic interaction between $\mathrm{B}$ and $\mathrm{K}$ might have increased dry matter yield significantly.

At 90 DAS, also similar trends were observed regarding shoot yield. Boron and potassium had significant effect on shoot yield. There was progressive increase in shoot yield from control to $\mathrm{B}_{1.5} \mathrm{~K}_{60}$. However, it is statistically at par with $\mathrm{B}_{1} \mathrm{~K}_{30}, \mathrm{~B}_{1} \mathrm{~K}_{60}$ and $\mathrm{B}_{1.5} \mathrm{~K}_{30}$. Increase in drymatter yield could be due to activation of some of the fundamental processes with B nutrient such as cell elongation and division as well as nucleic acid metabolism. (Shelp, 1993 and Ruiz et al., 1998)

Tiwari et al., (2012) reported that application of $\mathrm{K}$ up to $60 \mathrm{~kg} \mathrm{~K}_{2} \mathrm{O}$ ha $^{-1}$ also significantly increased shoot yields of mustard. Karthikeyan et al., (2008) noticed that significant increase in drymatter with the increasing levels of applied boron in mustard crop. Duyingqiong et al., (2002) reported that B fertilizer significantly enhanced photosynthetic activity of leaves, which consequently resulted in more accumulation of dry matter in peanut (Arachis hypogeal L.). Ahmed et al., (2011) also observed that dry matter yield increased significantly with B up to $2.0 \mathrm{~kg} \mathrm{ha}^{-1}$.

\section{Nitrogen uptake}

The results showed that boron and potassium levels significantly influenced nitrogen uptake by sunflower plant (Table 1). At 60 DAS, uptake of nitrogen varied from $33.24 \mathrm{~kg} \mathrm{ha}^{-1}$ to $71.39 \mathrm{~kg} \mathrm{ha}^{-1}$. Soil application of boron had significant effect on nitrogen and maximum $\mathrm{N}$ uptake was recorded with $1.5 \mathrm{~kg} \mathrm{~B} \mathrm{ha}^{-1}$ as compared to $0 \mathrm{~kg} \mathrm{~B} \mathrm{ha}{ }^{-1}$. However, it was statistically at par with $1 \mathrm{~kg} \mathrm{~B} \mathrm{ha}{ }^{-1}$. Potassium application also had significant effect on nitrogen uptake and there was gradual increase in nitrogen uptake with increasing levels of potassium. The highest nitrogen uptake was recorded in treatment $\mathrm{B}_{1.5} \mathrm{~K}_{60}$ however it is statistically on par with $\mathrm{B}_{1} \mathrm{~K}_{30}, \mathrm{~B}_{1} \mathrm{~K}_{60}$ and $\mathrm{B}_{1.5} \mathrm{~K}_{30}$ treatments.

Similar trend were noticed in N uptake at 90 DAS. The highest nitrogen uptake recorded with treatment $\mathrm{B}_{1.5} \mathrm{~K}_{60}$ which were on par with $\mathrm{B}_{1} \mathrm{~K}_{30}, \mathrm{~B}_{1} \mathrm{~K}_{60}$ and $\mathrm{B}_{1.5} \mathrm{~K}_{30}$ treatments, however it is significant over control (Table $1)$.

\section{Phosphorus uptake}

At 60 DAS, phosphorus uptake of shoot varied from $3.17 \mathrm{~kg} \mathrm{ha}^{-1}$ at control to $9.54 \mathrm{~kg} \mathrm{ha}^{-1}$ treatment. Soil application of boron had significant effect on phosphorus uptake and maximum $\mathrm{P}$ uptake was recorded with $1.5 \mathrm{~kg}$ $\mathrm{B} \mathrm{ha}^{-1}$ as compared to $0 \mathrm{~kg} \mathrm{~B} \mathrm{ha}{ }^{-1}$ (Table 1). However, it was statistically at par with $1 \mathrm{~kg} \mathrm{~B}$ $\mathrm{ha}^{-1}$. Potassium application also had significant effect on phosphorus uptake and there was a progressive increase in phosphorus uptake with increasing levels of potassium. 
The highest phosphorus uptake was recorded in treatment $\mathrm{B}_{1.5} \mathrm{~K}_{60}$, however it is statistically on par with $\mathrm{B}_{1} \mathrm{~K}_{60}, \mathrm{~B}_{1.5} \mathrm{~K}_{30}$ treatments. Similar trends were noticed in shoot $\mathrm{P}$ uptake at 90 DAS. The highest phosphorus uptake was recorded with treatment $\mathrm{B}_{1.5} \mathrm{~K}_{60}$ which were on par with $\mathrm{B}_{1} \mathrm{~K}_{30}, \mathrm{~B}_{1} \mathrm{~K}_{60}$ and $\mathrm{B}_{1.5} \mathrm{~K}_{30}$ treatments but significant over control (Table 1).

\section{Potassium uptake}

Potassium uptake at 60 DAS by shoot varied from $43.47 \mathrm{~kg} \mathrm{ha}^{-1}$ to $122.41 \mathrm{~kg} \mathrm{ha}^{-1}$. Soil application of boron had significant effect on potassium uptake and maximum mean $\mathrm{K}$ uptake was recorded with $1.5 \mathrm{~kg} \mathrm{~B} \mathrm{ha}^{-1}$ as compared to $0 \mathrm{~kg} \mathrm{~B} \mathrm{ha}^{-1}$ (Table 1).

However, it was statistically at par with $1 \mathrm{~kg} \mathrm{~B}$ $\mathrm{ha}^{-1}$.Potassium application also had significant effect on shoot potassium uptake and there was a progressive increase in potassium uptake with increasing levels of potassium. The highest potassium uptake was recorded in treatment $\mathrm{B}_{1.5} \mathrm{~K}_{60}$, however it is statistically on par with $\mathrm{B}_{1.5} \mathrm{~K}_{30}$ treatment.

Similar trend were noticed in shoot $\mathrm{K}$ uptake at 90 DAS. The highest potassium uptake recorded with treatment $1.5 \mathrm{~kg} \mathrm{~B} \mathrm{ha}^{-1}+60 \mathrm{~kg}$ $\mathrm{K} \mathrm{ha}^{-1}$ which was on par with $\mathrm{B}_{1} \mathrm{~K}_{30}, \mathrm{~B}_{1} \mathrm{~K}_{60}$ and $\mathrm{B}_{1.5} \mathrm{~K}_{30}$ treatments but significant over control. Brar et al., (2010) reported that potassium uptake by straw was more as compared to the seeds. This was due to high content of $\mathrm{K}$ in straw than the grains. K uptake increased with the increase in levels of applied potassium.

Application of $90 \mathrm{~kg} \mathrm{~K}_{2} \mathrm{O} \mathrm{ha}^{-1}$ increased the $\mathrm{K}$ uptake from 22.1 to $34.4 \mathrm{~kg} \mathrm{ha}^{-1}$ in seeds and from 102.4 to $154.2 \mathrm{~kg} \mathrm{ha}^{-1}$ in straw over no $\mathrm{K}$ application. Bestas and Celik (2013) reported that in sunflower the highest potassium uptake was found at 4.0 and $8.0 \mathrm{mg} \mathrm{B} \mathrm{kg}^{-1}$ doses.

\section{Boron uptake}

Boron uptake by sunflower was significantly influenced by boron and potassium levels.At 60 DAS, boron uptake by sunflower varied from $65.21 \mathrm{~g} \mathrm{ha}^{-1}$ to $286.05 \mathrm{~g} \mathrm{ha}^{-1}$ Soil application of boron had significant effect on boron uptake and maximum B uptake was recorded with $1.5 \mathrm{~kg} \mathrm{~B} \mathrm{ha}^{-1}$ as compared to 0 $\mathrm{kg} \mathrm{B} \mathrm{ha-1}$. However, it was statistically at par with $1 \mathrm{~kg} \mathrm{~B} \mathrm{ha}^{-1}$ (Table 1). Potassium application also had significant effect on boron uptake and there was a progressive increase in mean B uptake with increasing levels of potassium. The highest B uptake was recorded in treatment $\mathrm{B}_{1.5} \mathrm{~K}_{60}$ however it is statistically on par with $\mathrm{B}_{1.0} \mathrm{~K}_{30}$ treatment.

Similar trend was noticed in shoot B uptake at 90 DAS. The highest boron uptake recorded with treatment $1.5 \mathrm{~kg} \mathrm{~B} \mathrm{~kg} \mathrm{ha}^{-1}+60 \mathrm{~kg} \mathrm{~K} \mathrm{~kg}$ $\mathrm{ha}^{-1}$ which were on par with $\mathrm{B}_{1} \mathrm{~K}_{60}$ and $\mathrm{B}_{1.5} \mathrm{~K}_{30}$ treatments, however it was significant over control (Table 1).

\section{Seed yield}

Sunflower seed yield among the various B and $\mathrm{K}$ treatments ranged from 952.8 to $1430 \mathrm{~kg}$ $\mathrm{ha}^{-1}$ (Table 2). Soil application of boron had significant effect on seed yield and maximum yield was recorded with $1.5 \mathrm{~kg} \mathrm{~B} \mathrm{ha}^{-1}$ as compared to control. However, it was statistically at par with $1 \mathrm{~kg} \mathrm{~B} \mathrm{ha}^{-1}$ (Table 2).

Potassium application also had significant effect on yield and there was progressive increase in seed yield from 969.4 to $1334 \mathrm{~kg}$ $\mathrm{ha}^{-1}$ with increasing levels of potassium i.e. 0 to $60 \mathrm{~kg} \mathrm{ha}^{-1}$. The highest seed yield was recorded in treatment $\mathrm{B}_{1.5} \mathrm{~K}_{60}$, however it is statistically on par with $\mathrm{B}_{1} \mathrm{~K}_{30}, \mathrm{~B}_{1} \mathrm{~K}_{60}$ and $\mathrm{B}_{1.5}$ $\mathrm{K}_{30}$ treatments. Seed yield was also significantly influenced by $\mathrm{B}$ x $\mathrm{K}$ interaction (Table 2). 
Adequate supply of recommended dose of fertilizers along with boron and potassium application had positively reflected in attaining higher seed yield. Boron known to play major role in improving the head diameter and viability, germination and growth of pollen tubes which in turn might have resulted in more filled seeds. Seed yield increased through potassium application may be due to its key role in increasing crop yield and improving the quality of product and hence, the transport of nutrients is essential to metabolism in active areas. Similar results were obtained by Ahmed et al., (2001) who found that head diameter, weight of thousand seed and seed yield increased with increasing potassium application rates from 0 to $150 \mathrm{~kg}$ $\mathrm{ha}^{-1}$.

Renukadevi et al., (2002) studied the effect of different levels of boron $(0.5,1.0,1.5$ and 2.0 $\mathrm{kg} \mathrm{ha}^{-1}$ ) as soil application and two levels of foliar spray $(0.2 \%$ and $0.3 \%)$.The highest seed yield was recorded for the soil application of B @ $2.0 \mathrm{~kg} \mathrm{ha}{ }^{-1}$. The yield increase in sunflower was 3.6 to 15.8 per cent and 7.2 to 18.9 per cent over the control for both seed and stalk, respectively.

\section{Nitrogen uptake}

At harvest seed uptake of nitrogen was significantly affected by boron and potassium levels. Uptake of seed nitrogen varied from $28.81 \mathrm{~kg} \mathrm{ha}^{-1}$ to $43.83 \mathrm{~kg} \mathrm{ha}^{-1}$ with the treatments $\mathrm{B}_{1.5} \mathrm{~K}_{60}$ and $\mathrm{B}_{0} \mathrm{~K}_{0}$ (Table 2). $\mathrm{B} \times \mathrm{K}$ interactions showed significant influence on nitrogen uptake. Brar et al., (2010) reported that the significant increase in $\mathrm{N}$ uptake by sunflower seeds was noticed with the application of increased levels of potassium application and the highest crop uptake was noticed at $90 \mathrm{~kg} \mathrm{~K}_{2} \mathrm{O} \mathrm{ha}{ }^{-1}$. The increase in shoot $\mathrm{N}$ uptake was mainly due to increase in shoot yield.

\section{Phosphorus uptake}

At harvest seed uptake of phosphorus was significantly affected by boron and potassium levels. Uptake of seed phosphorus varied from $8.37 \mathrm{~kg} \mathrm{ha}^{-1}$ to $13.73 \mathrm{~kg} \mathrm{ha}^{-1}$ with the treatments of control and $1.5 \mathrm{~kg} \mathrm{~B} \mathrm{ha}^{-1}+30 \mathrm{~kg}$ $\mathrm{K} \mathrm{ha}^{-1}$. B x K interactions showed significant influence on phosphorus uptake (Table 2). Ramulu et al., (2011) reported that phosphorus uptake significantly affected by the different levels boron. Brar et al., (2010) reported that phosphorus uptake both by seeds and straw increased with the application of both phosphorus and potassium.

\section{Potassium uptake}

At harvest seed uptake of potassium was significantly influenced by boron and potassium levels. Uptake of seed potassium varied from $8.09 \mathrm{~kg} \mathrm{ha}^{-1}$ to $3.90 \mathrm{~kg} \mathrm{ha}^{-1}$ with the treatments of $1.5 \mathrm{~B} \mathrm{~kg} \mathrm{ha}^{-1}+30 \mathrm{~K} \mathrm{~kg} \mathrm{ha}^{-1}$ and control. $\mathrm{B} \quad \mathrm{x} \quad \mathrm{K}$ interactions also significantly influenced the potassium uptake by sunflower (Table 2 ).

\section{Boron uptake}

At harvest seed uptake of boron was significantly influenced by boron and potassium levels. Uptake of seed boron varied from $8.56 \mathrm{~kg} \mathrm{ha}^{-1}$ to $32.63 \mathrm{~kg} \mathrm{ha}^{-1}$ with the treatments of $1.5 \mathrm{~kg} \mathrm{~B} \mathrm{ha}^{-1}+30 \mathrm{~kg} \mathrm{~K} \mathrm{ha}^{-1}$ and control. $\mathrm{B} \quad \mathrm{X} \quad \mathrm{K}$ interaction was also significantly influenced potassium uptake (Table 2). Siddiqui et al., (2009) reported that the soil incorporation of $15 \mathrm{~kg} \mathrm{Zn} \mathrm{ha}^{-1}$ and 1.5 $\mathrm{kg} \mathrm{B} \mathrm{ha}{ }^{-1}$ doses recorded B uptake (157.53 g $\left.\mathrm{ha}^{-1}\right)$. Unfertilized plots recorded lower nutrient uptake values.

Thus, in the present investigation, the increasing level of $\mathrm{B}$ and $\mathrm{K}$, increased the drymatter production at 60 and 90 DAS. 
Table.1 Effect of boron and potassium levels on drymatter yield and uptake of nitrogen, phosphorus, potassium and boron by sunflower (cv. GK 2002) shoot at 60 and 90 days

\begin{tabular}{|c|c|c|c|c|c|c|c|c|c|c|}
\hline \multicolumn{6}{|c|}{$\mid$} & \multicolumn{5}{|c|}{90 days } \\
\hline \multicolumn{11}{|c|}{ Drymatter yield $(\mathrm{kg} / \mathrm{ha})$} \\
\hline \multirow{2}{*}{$\begin{array}{l}\text { Potassium } \\
\left(\mathrm{kg} \mathrm{ha}^{-1}\right)\end{array}$} & \multicolumn{4}{|c|}{ Boron $\left(\mathrm{kg} \mathrm{ha}^{-1}\right)$} & \multirow[t]{2}{*}{ Mean } & \multicolumn{4}{|c|}{ Boron $\left(\mathrm{kg} \mathrm{ha}^{-1}\right)$} & \multirow[t]{2}{*}{ Mean } \\
\hline & 0 & 0.5 & 1 & 1.5 & & 0 & 0.5 & 1 & 1.5 & \\
\hline 0 & 1504.33 & 1514.00 & 1520.67 & 1526.00 & 1516.25 & 2204.3 & 2214.0 & 2220.7 & 2226.0 & 2216.3 \\
\hline 15 & 2046.96 & 2320.00 & 2794.67 & 2851.00 & 2503.16 & 3067.0 & 3340.0 & 3814.7 & 3871.0 & 3523.2 \\
\hline 30 & 2343.67 & 2576.33 & 3131.33 & 3157.00 & 2802.08 & 3443.7 & 3676.3 & 4231.3 & 4200.0 & 3887.8 \\
\hline 60 & 2456.33 & 2814.00 & 3146.00 & 3188.00 & 2901.08 & 3556.3 & 3914.0 & 4246.0 & 4275.0 & 3997.8 \\
\hline Mean & 2087.82 & 2306.08 & 2648.17 & 2680.50 & & 3067.8 & 3286.1 & 3628.2 & 3643.0 & \\
\hline & & \multicolumn{2}{|c|}{$\mathrm{SEm} \pm$} & \multicolumn{2}{|c|}{$\mathrm{CD}(\mathrm{P}=0.05)$} & \multicolumn{2}{|c|}{$\mathrm{SEm} \pm$} & \multicolumn{2}{|c|}{$\mathrm{CD}(\mathrm{P}=0.05)$} & \\
\hline \multicolumn{2}{|l|}{ Boron levels } & \multicolumn{2}{|c|}{42.8} & \multicolumn{2}{|c|}{123.7} & \multicolumn{2}{|c|}{46.5} & \multicolumn{2}{|c|}{134.5} & \\
\hline Potassium le & & & & $12 ?$ & & 46 & & 13 & & \\
\hline Interaction ( $\mathrm{F}$ & & & & 247 & & 93 & & 26 & & \\
\hline Nitrogen uptc & $(\mathrm{kg} / \mathrm{ha})$ & & & & & & & & & \\
\hline 0 & 33.24 & 33.59 & 33.40 & 33.86 & 33.52 & 27.23 & 27.45 & 27.61 & 27.68 & 27.49 \\
\hline 15 & 44.96 & 51.67 & 62.29 & 63.55 & 55.62 & 38.03 & 41.30 & 47.42 & 47.87 & 43.66 \\
\hline 30 & 52.00 & 57.41 & 69.80 & 70.71 & 62.48 & 42.69 & 46.19 & 53.29 & 53.83 & 49.00 \\
\hline 60 & 54.69 & 61.60 & 70.86 & 71.39 & 64.64 & 44.11 & 48.93 & 53.64 & 53.91 & 50.15 \\
\hline Mean & 46.22 & 51.07 & 59.09 & 59.88 & & 38.01 & 40.97 & 45.49 & 45.82 & \\
\hline & & & & $\mathrm{CD}(\mathrm{P}=$ & $0.05)$ & SE & & $\mathrm{CD}(\mathrm{P}$ & $.05)$ & \\
\hline Boron levels & & & & 3. & & 0. & & 1. & & \\
\hline Potassium le & & & & 3. & & 0 . & & 1. & & \\
\hline Interaction ( $\mathrm{F}$ & K) & & & 6. & & & & 3. & & \\
\hline Phosphorus 2 & ake $(\mathrm{kg} / \mathrm{ha})$ & & & & & & & & & \\
\hline 0 & 3.17 & 3.42 & 3.49 & 3.64 & 3.43 & 1.56 & 1.74 & 2.06 & 2.06 & 1.85 \\
\hline 15 & 4.97 & 5.78 & 7.27 & 7.42 & 6.36 & 3.22 & 4.18 & 4.55 & 4.85 & 4.20 \\
\hline 30 & 6.11 & 7.24 & 8.64 & 9.13 & 7.78 & 4.63 & 4.61 & 6.09 & 6.15 & 5.37 \\
\hline 60 & 6.96 & 8.08 & 9.21 & 9.54 & 8.45 & 4.82 & 5.84 & 6.29 & 6.37 & 5.83 \\
\hline Mean & 5.30 & 6.13 & 7.15 & 7.43 & & 3.56 & 4.09 & 4.75 & 4.86 & \\
\hline & & & & $\mathrm{CD}(\mathrm{P})$ & $0.05)$ & SE & & $\mathrm{CD}(\mathrm{P}$ & $.05)$ & \\
\hline Boron levels & & 0. & & 0. & & 0. & & 0 . & & \\
\hline Potassium le & & 0 . & & 0.6 & & 0 . & & 0 . & & \\
\hline Interaction ( & K) & & & $\mathrm{N}$ & & 0 . & & $\mathrm{N}$ & & \\
\hline Potassium up & e $(\mathrm{kg} / \mathrm{ha})$ & & & & & & & & & \\
\hline 0 & 43.47 & 44.21 & 45.01 & 45.62 & 44.58 & 48.79 & 24.40 & 50.56 & 51.20 & 41.25 \\
\hline 15 & 67.28 & 80.61 & 101.25 & 104.92 & 88.51 & 76.99 & 46.00 & 103.32 & 107.48 & 75.44 \\
\hline 30 & 80.03 & 93.79 & 118.57 & 120.70 & 103.27 & 91.07 & 60.54 & 132.37 & 135.81 & 94.66 \\
\hline 60 & 86.57 & 104.70 & 119.83 & 122.41 & 108.38 & 95.97 & 77.98 & 135.96 & 138.03 & 103.31 \\
\hline Mean & 69.34 & 80.83 & 96.16 & 98.41 & & 78.21 & 52.23 & 105.55 & 108.13 & \\
\hline & & & & $\mathrm{CD}(\mathrm{P}=$ & $0.05)$ & SE & & $\mathrm{CD}(\mathrm{P}$ & $.05)$ & \\
\hline Boron levels & & & & 4 & & & & 6. & & \\
\hline Potassium le & & & & 4. & & & & 6. & & \\
\hline Interaction ( & & & & 9.8 & & & & 13 & & \\
\hline Boron uptake & ha) & & & & & & & & & \\
\hline 0 & 65.21 & 70.44 & 76.93 & 92.81 & 76.35 & 35.65 & 39.59 & 42.44 & 46.89 & 41.14 \\
\hline 15 & 105.45 & 144.91 & 216.51 & 249.19 & 179.01 & 53.16 & 68.75 & 85.61 & 96.36 & 75.97 \\
\hline 30 & 135.71 & 202.25 & 275.65 & 282.44 & 224.01 & 62.22 & 82.62 & 112.88 & 115.85 & 93.39 \\
\hline 60 & 150.81 & 221.09 & 282.46 & 286.05 & 235.10 & 66.84 & 89.54 & 114.20 & 115.51 & 96.52 \\
\hline Mean & 114.29 & 159.67 & 212.89 & 227.62 & & 54.47 & 70.13 & 88.78 & 93.65 & \\
\hline & & SE & & $\mathrm{CD}(\mathrm{P}$ & $0.05)$ & SE & & $\mathrm{CD}(\mathrm{P}$ & $.05)$ & \\
\hline Boron levels & & & & 22 & & & & 5 & & \\
\hline Potassium le & & & & 22. & & & & & & \\
\hline Interaction ( & K) & & & 44. & & 4. & & 11 & & \\
\hline
\end{tabular}


Table.2 Effect of boron and potassium levels on seed yield and uptake of nitrogen, phosphorus, potassium and boron by sunflower (cv. GK 2002) seed

\begin{tabular}{|c|c|c|c|c|c|}
\hline \multicolumn{6}{|l|}{ Seed yield $(\mathrm{kg} / \mathrm{ha})$} \\
\hline \multirow{2}{*}{ Potassium $\left(\mathrm{kg} \mathrm{ha}^{-1}\right)$} & \multicolumn{4}{|c|}{ Boron $\left(\mathrm{kg} \mathrm{ha}^{-1}\right)$} & \multirow[t]{2}{*}{ Mean } \\
\hline & 0 & 0.5 & 1 & 1.5 & \\
\hline $\mathbf{0}$ & 952.8 & 961.3 & 975.3 & 988.0 & 969.4 \\
\hline 15 & 1025.3 & 1114.7 & 1272.0 & 1290.7 & 1175.7 \\
\hline 30 & 1156.0 & 1226.0 & 1410.7 & 1419.3 & 1303.0 \\
\hline 60 & 1187.0 & 1305.7 & 1416.0 & 1430.0 & 1334.7 \\
\hline \multirow[t]{2}{*}{ Mean } & 1080.3 & 1151.9 & 1268.5 & 1285.1 & \\
\hline & & \multicolumn{2}{|c|}{ SEm \pm} & \multicolumn{2}{|c|}{$\mathrm{CD}(\mathrm{P}=0.05)$} \\
\hline \multicolumn{2}{|l|}{ Boron levels } & \multicolumn{2}{|c|}{$16.2^{-}$} & \multicolumn{2}{|c|}{46.8} \\
\hline \multicolumn{2}{|l|}{ Potassium levels } & \multicolumn{2}{|c|}{16.2} & \multicolumn{2}{|c|}{46.8} \\
\hline \multicolumn{2}{|l|}{ Interaction (B x K) } & \multicolumn{2}{|l|}{32.4} & \multicolumn{2}{|c|}{93.7} \\
\hline \multicolumn{6}{|c|}{ Nitrogen uptake $(\mathrm{kg} / \mathrm{ha})$} \\
\hline o & 28.81 & 29.09 & 29.49 & 29.87 & 29.31 \\
\hline 15 & 31.30 & 34.11 & 38.92 & 39.50 & 35.96 \\
\hline 30 & 35.27 & 37.50 & 43.18 & 43.52 & 39.87 \\
\hline 60 & 36.33 & 40.03 & 43.42 & 43.83 & 40.90 \\
\hline \multirow[t]{2}{*}{ Mean } & 32.93 & 35.18 & 38.75 & 39.18 & \\
\hline & & \multicolumn{2}{|c|}{$\mathrm{SEm} \pm$} & \multicolumn{2}{|c|}{$\mathrm{CD}(\mathrm{P}=0.05)$} \\
\hline Boron levels & & 0.53 & & 1 & \\
\hline Potassium levels & & 0.53 & & 1. & \\
\hline Interaction (B x K) & & 1.05 & & 3. & \\
\hline Phosphorus uptake (I & & & & & \\
\hline 0 & 8.37 & 8.15 & 8.21 & 8.65 & 8.35 \\
\hline 15 & 9.46 & 10.40 & 11.84 & 12.26 & 10.99 \\
\hline 30 & 10.43 & 11.50 & 13.34 & 13.73 & 12.25 \\
\hline 60 & 11.40 & 12.38 & 13.63 & 13.65 & 12.76 \\
\hline Mean & 9.92 & 10.61 & 11.76 & 12.07 & \\
\hline & & $\mathrm{SEm}-$ & & $\mathrm{CD}(\mathrm{P}$ & \\
\hline Boron levels & & 0.17 & & 0 & \\
\hline Potassium levels & & 0.17 & & 0 & \\
\hline Interaction (B x K) & & 0.34 & & 0 & \\
\hline Potassium uptake $(k g$ & & & & & \\
\hline O & 3.90 & 3.91 & 3.96 & 4.32 & 4.02 \\
\hline 15 & 4.75 & 5.27 & 6.16 & 6.20 & 5.59 \\
\hline 30 & 5.97 & 6.73 & 7.85 & 7.91 & 7.12 \\
\hline 60 & 6.52 & 7.45 & 8.02 & 8.09 & 7.52 \\
\hline Mean & 5.28 & 5.84 & 6.50 & 6.63 & \\
\hline & & $\mathrm{SEm}-$ & & $\mathrm{CD}(\mathrm{P}$ & \\
\hline Boron levels & & 0.15 & & 0 & \\
\hline Potassium levels & & 0.15 & & 0. & \\
\hline Interaction (B x K) & & 0.3 & & 0. & \\
\hline Boron uptake (g/ha) & & & & & \\
\hline 0 & 8.56 & 14.93 & 15.45 & 16.32 & 13.82 \\
\hline 15 & 10.36 & 19.97 & 23.39 & 26.16 & 19.97 \\
\hline 30 & 12.44 & 22.40 & 30.99 & 32.00 & 24.46 \\
\hline 60 & 12.94 & 24.17 & 30.88 & 32.63 & 25.15 \\
\hline Mean & 11.08 & 20.37 & 25.18 & 26.78 & \\
\hline & & $\mathrm{SEm}-$ & & $\mathrm{CD}(\mathrm{P}$ & \\
\hline Boron levels & & 0.6 & & 1 & \\
\hline Potassium levels & & 0.6 & & 1. & \\
\hline Interaction (B x K) & & 1.21 & & & \\
\hline
\end{tabular}


The $\mathrm{B} \times \mathrm{K}$ interaction was found significant with respect to drymatter. Sunflower shoot uptake of major nutrients like $\mathrm{N}$ and $\mathrm{P}$ were significantly influenced by the application of $B$ and $K$ at 60 and 90 DAS.

Nutrient uptake by sunflower seed increased with increasing levels of boron and potassium application. Seed nutrient uptake of N, P, K and $\mathrm{B}$ were $43.83,11.85,13.65 \mathrm{~kg} \mathrm{ha}^{-1}$ and $33.24 \mathrm{~kg} \mathrm{ha}^{-1}$, respectively with $\mathrm{B}_{1.5} \mathrm{~K}_{60}$, which is at par with $\mathrm{B}_{1} \mathrm{~K}_{30}$ treatment.

\section{References}

Ahmed, N., Abid, M., Ahmad, F., Aman Ullah, M., Javaid, Q and Ali, M. A. 2011.Impact of boron fertilization on dry matter production and mineral constitution of irrigated cotton. Pakistan Journal of Botany.43 (6): 2903-2910.

Asad, A., Blamey, F.P.C and Edwards, D.G. 2003.Effects of boron foliar applications on vegetative and reproductive growth of sunflower.Annals of Botany. 92: 565570.Bestas and Celik 2013

Bhupal Raj, G., Singh, M.V., Patnaik, M. C and Khadke, K.M. 2009. Four decades of research on micro and secondarynutrients and pollutant elements in Andhra Pradesh. Research Bulletin. AICRP Micro-and SecondaryNutrients and Pollutant Elements in Soils and Plants, IISS, Bhopal. pp: 1132.

Blamey, F. P. C and Chapman, J. 1982.Differential response of two sunflower cultivars to Boron fertilization. In Proceedings of the $10^{\text {th }}$ International Sunflower Conference, Surfers Paradise, Australia. 14-18 March, 1982. International Sunflower Association. Paris, France. pp: 92-94.

Brar, M. S., Sharma, P., Singh, A., Dhillon,
N. S and Sindhu, S. S. 2010. Effect of potassium nutrition on the yield, quality and nutrient uptake by sunflower. Journal of the Indian Society of Soil Science. 58 (3): 344346.

Chatterjee, C and NautiyalN. 2000. Developmental aberrations in seeds of boron deficient sunflower and recovery. Journal of Plant Nutrition. 23: $835-841$.

Duyingqiong, Q., Liao Xinrong., He Jianghua, Hiang Zhoyao and Zhou Xiaohong. 2002. Effect of B and Mo on the growth, development and yield of peanut. Plant Nutrition and Fertilizer Science. 8 (2): 233-235.

Gaines, T.P and Mitchell, G.A. 1979. Boron determination in plant tissue by the Azomethine-H method. Communications in Soil Science and plant analysis. 10(8): 1099-1108.

Karthikeyan, K and Shukla, L.M. 2008.Effect of boron-sulphur interaction on their uptake and quality parameters of mustard (Brassica juncea L.) and sunflower (Helianthus annus L.) Journal of the Indian Society of Soil Science. 56(2): 225-230.

Murthy, I.Y.L.N., Padmavathi P and Padmaiah M 2009. Critical level of DTPA-Zn for castor (Ricinus communis L.) in Alfisols. Agropedology, 19(2):139-142.

Pathak H. 2010. Trend of fertility status of Indian soils. Current Advances in Agricultural Sciences. 2(1): 10-12.

Piper, C. S. 1966. Soil and plant analysis. Hans publishers, Bombay. 47-49: 81111.

Ramulu, N., Jayadeva, H.M., Venkatesha, M.M and Kumar, H.R. 2011. Seed yield and nutrient uptake of Sunflower (Helianthus annuus L.) as influenced by different levels of nutrients under irrigated condition of Eastern Dry 
Zone of Karnataka, India. Plant Archives. 11: 1061-1066.

Rego, Thomas J., Sahrawat, Kanwar L.,wani, Suhas $\mathrm{P}$ and Pardhasaradhi, Gazula. 2007. Wide spread Deficiencies of S, $\mathrm{B}, \mathrm{Zn}$ in Indian Semi-arid tropical Soils (on farm crop responses). Journal of Plant nutrition. 30 (10): 1569-1583.

Renukadevi, A., Savithri, P and Andi, K. 2002. Evaluation of boron fertilizers for a sunflower (Helianthus annuusL.) - green gram (Vigna radiata L.) cropping sequence in Inceptisols. Acta Agronomica Hungarica. 50(2):163168.

Ruiz, J.M., Baghour, M., Bretones, G., Belakir, $\mathrm{A}$ and Romero, L. 1998.Nitrogen metabolism in tobacco plants (Nicotiana tabacum L.): Role of boron as a possible regulatory factor. International Journal of Plant Science.159: 121-126.

Sahrawat, K L and Wani, S P and Rego, T J and Pardhasaradhi, G and Murthy, $\mathrm{K}$ V S 2007 Widespread deficiencies of sulphur, boron and zinc in dryland soils of the Indian semi-arid tropics. Current Science, 93 (10). pp. 14281432.

Shelp, B.J. 1993. Physiology and biochemistry of boron in plants. In
Boron and Its Role in crop Production, ed. UC Gupta, pp. 53-85. Boca Raton, FL: CRC Press.

Shukla, A.K., Tiwari, P.K and Prakash, C. 2014. Micronutrients deficiencies visà-vis food and nutritional security of India. Indian Journal Fertilizers. 10(12): 94-112.

Siddiqui, M.H., Oad, F.C., Kaleem, A.M and Gandhi, A.W. 2009.Zinc and Boron fertility to optimize physiological parameters, nutrient uptake and seed yield of Sunflower. Sarhad Journal Agriculture.25(1): 53-57.

Sirbu, M and Ailincai. D. 1992. Effect of long term Fertilizer application including NPK on the grain yields and quality of sunflower. Agronomy in Mold. 25:181-187.

Soleimanzadeh, H., Habibi, D., Ardakani, M.R., Paknejad, F and Rejali, F. 2010. Response of sunflower (Helianthus Аnпии L.) to drought stress under different potassium levels. World Applied Sciences Journal. 8(4): 443448.

Ujwala, R.M. 2011. Interaction of micronutrients with major nutrients with special reference to potassium. Karnataka Journal of Agricultural Sciences. 24 (1): 106-109.

\section{How to cite this article:}

Jyothi, P., T. Anjaiah, I.Y.L.N. Murthy, Rajeshwar Naik and Hussain, S.A. 2018. Seed Yield and Nutrient Uptake of Sunflower (Helianthus anпииs L.) as Influenced by Different Levels of Boron and Potassium in Sandy Loam Soil. Int.J.Curr.Microbiol.App.Sci. 7(07): 3684-3692. doi: https://doi.org/10.20546/ijcmas.2018.707.425 